ESSAYS

(cc) BY 4.0

\title{
THE AGE OF DIGITALIZATION: TENDENCIES OF THE LABOR MARKET
}

\author{
Liu Dun', Geng Yuann, ${ }^{2 *}$, Yuan Lunqu' \\ ${ }^{1}$ Beijing Jiaotong University \\ 3, Shangyuancun, Haidian District Beijing, People's Republic of China, \\ 100044 \\ ${ }^{2}$ Capital University of Economics and Business \\ 121, Zhangjialukou, Huaxiang Fengtai District, Beijing, People's Republic \\ of China, 100070
}

\section{Abstract}

This essay presents the main trends of changes in the labor market in connection with the digitalization of the world economy. The interrelated problems of increasing labor productivity, reducing workplaces, and ensuring effective demand are considered. The authors propose considering digitalization as a way of promoting creativity in workplaces, albeit having a delayed effect due to the lag in time for the establishment of a world new economic order, during which services are becoming the main product, and digital platforms and ecosystems are the main actors in the global economy. "Creativization" is a new term suggested by the authors, which means a workplace that is being transformed by digitalization, whereby monotonous work processes are replaced by intellectually intensive operations, art elements, and unique high-performance activities.

\section{Keywords}

digitalization, labor market, creativization of workplaces, basic income

\section{The authors declare no conflict of interest. \\ The study had no sponsorship.}

For citation

\section{Conflict of interest \\ Financial disclosure \\ Acknowledgements}

Acknowledgements
The authors would like to offer their warm words and thanks to MGIMO University for their invitation to publish this essay in the pages of Digital Law Journal. The authors hope that the cooperation between Beijing Jiaotong University, Capital University of Economics and Business, and MGIMO University will increase in the future.

Dun, L., Yuan, G., \& Lunqu, Y. (2020). The age of digitalization: Tendencies of the labor market. Digital Law Journal, 1(3), 14-20. https://doi.org/10.38044/26869136-2020-1-3-14-20

\section{* Corresponding author}

Submitted: 15 Jun. 2020, accepted: 07 Aug. 2020, published: 30 Sep. 2020 


\title{
ТЕНДЕНЦИИ РЫНКА ТРУДА В ЭПОХУ ЦИФРОВИЗАЦИИ
}

\author{
Л. Дунь', Г. Юань ${ }^{2 *}$, Ю. Луньцюй
}

\author{
${ }^{1}$ Пекинский университет Цзяотун \\ 100044, Китайская Народная Республика, Пекин, район Хайдянь, \\ Шангуянькун, 3 \\ ${ }^{2}$ Столичный университет экономики и бизнеса \\ 100070, Китайская Народная Республика, Пекин, район Хуатсианг \\ Фенгтай, Джангдзиалюкоу, 121
}

\section{Аннотация}

В настоящем эссе представлен анализ основных изменений на рынке труда, вызванных цифровизацией мировой экономики. Рассмотрены взаимосвязанные проблемы повышения производительности труда, сокращения рабочих мест и обеспечения платежеспособного спроса. Авторы предлагают рассматривать цифровизацию как фактор, способствующий развитию творческого потенциала работников на рабочих местах, что сопровождается установлением нового мирового экономического порядка, в котором услуги становятся основным продуктом. Цифровые платформы и экосистемы играют основополагающую роль в мировой экономике. «Креативизация» - новый термин, предложенный авторами, связанный с обозначенными выше процессами, при которых монотонные рабочие процессы все более усложняются и требуют интеллектуальной отдачи, а также нестандартного мышления.

\section{Ключевые слова}

цифровизация, рынок труда, креативизация рабочих мест, базовый доход

\author{
Конфликт интересов Авторы сообщают об отсутствии конфликта интересов. \\ Финансирование Исследование не имело спонсорской поддержки. \\ Благодарности Авторы выражают благодарность МГИМО за приглашение принять участие \\ в научной дискуссии на страницах журнала «Цифровое право» (Digital \\ Law Journal) и надеются на плодотворное развитие сотрудничества меж- \\ ду мгИМО, Пекинским университетом Цзяотун и Столичным университетом \\ экономики и бизнеса.
}

Для цитирования Дунь, Л., Юань, Г., Луньцюй, Ю. (2020). Тенденции рынка труда в эпоху цифровизации. Цифровое право, 1(3), 14-20. https://doi.org/10.38044/2686-91362020-1-3-14-20

* Автор, ответственный за переписку

Поступила: 15.06.2020, принята в печать: 07.08.2020, опубликована: 30.09 .2020 
In this essay, we would like to share our observations of changes in the labor market during the period of mass digitalization of business, government, and society in the world. When labor market and wage reforms began in China, it was difficult to imagine that the labor market would change so rapidly in a few decades. This situation is limited, however, in terms of China's population, average age, and the prevalence of young people in the total population. For example, to provide the population with income, it is necessary to create about 10-15 million new jobs annually; if the trend of population growth continues, the demand for new workplaces may increase even more. However, the opposite effect has a gradual decrease in the share of young people in the working-age population.

Chairman Xi Jinping has pointed out that "we should take advantage of the historical opportunities that the digital economy provides to increase the medium and long-term growth potential of the global economy" .

According to Premier of the State Council Li Keqiang, the post-COVID development of the Chinese economy is already showing positive signals of revival: in April, for the first time since the beginning of the year, industrial production in the country showed an increase of $3.9 \%$. China aims to create more than 9 million new workplaces this year, and unemployment will be kept at $6 \%$. Another important limiting component is the level of the digitalization of the economy. For example, in accordance with the definition of a digital economy provided by the OECD methodology, China's digital economy forms about $6 \%$ of the country's GDP. The Chinese officials have set a goal to increase the share of GDP made from the digital economy to $50 \%$ by $2030^{2}$.

In terms of the digitalization of the economy, China demonstrates the global average, which adds to the discussion about choosing the development path through either a free or a regulated market economy. A free market economy, as is well known, is characteristic for Western countries, whilst a regulated market economy is characteristic for Eastern countries. Undecided about either path of development, countries are trying to alternately implement both models, in search of a recipe for overcoming the global economic crisis (caused largely by the coronavirus pandemic). A free-market economy, through self-regulation, forms a new economic order due to increased unemployment and a decrease in the price of labor, which gives hope for the creation of new workplaces and a new round of economic growth based on the digitalization of the economy. Institutionally, this is expressed in the creation and dominance of digital platforms and ecosystems in the market that can significantly increase the efficiency of production operations in the value chain.

The regulated market economy - the model of which has been implemented in China in its most complete form - provides for enhancing government participation in creating new workplaces, increasing employment, and launching new economic growth through effective demand. In both models, as can be seen, the central point belongs to the labor market: that is, through it a new round of economic growth will be carried out, albeit due to different instruments and, accordingly, with different consequences for the income of the population and the level of their life satisfaction. Highly developed Western countries can afford a more "brutal" and faster way to ensure economic growth, as poverty is understood in very different ways in Western and Eastern countries. The population of

China Daily. (2016, September 28). G20 digital economy development and cooperation initiative delivered at $2016 \mathrm{Hang}$ zhou summit renews impetus to global economy. http:// www.chinadaily.com.cn/business/2016hangzhoug20/2016-09/28/ content_26927065.htm

Zhang, L., \& Chen, S. (2019). China's digital economy: Opportunities and risks (Working Paper No. 19/16). International Monetary Fund. https://www.imf.org/en/Publications/WP/Issues/2019/01/17/Chinas-Digital-Economy-Opportunitiesand-Risks-46459 
rich countries during a period of unemployment receives benefits from the state, which significantly exceeds wages in the Eastern countries.

It could be countered that prices in these countries for food and utilities differ significantly. We agree with this only in part, since the possibilities for rich countries to support the poor are higher, and therefore the number of the poor (both in absolute terms and in percentage terms) is much higher in Eastern countries, which are just gaining speed in economic development and catching up with rich highly developed countries. Incidentally, the basic income model can be used in rich countries as a tool for regulating workplaces cuts due to the digitalization of the economy. This model is hardly applicable in Eastern countries, both due to the vastly larger population, and due to the lack of financial resources in the state budget, being burdened with the creation of production, transport, and social infrastructure.

The presence of a large number of working, able-bodied people employed in agriculture also has turned out to be a constraining factor for increasing labor productivity, since even digital technologies in agriculture increase it comparatively less than in industry due to the peculiarities of agricultural production.

The problem of interaction between, and the mutual influence of, labor and capital was examined in detail by Karl Marx. He noted that since the demand for labor is determined not by the amount of capital as a whole but by its variable constituent alone, that demand falls progressively with the increase of the total capital, instead of, as previously assumed, rising in proportion to it. It falls relative to the magnitude of the total capital, and at an accelerated rate as this magnitude increases. However, in fact, it is capitalistic accumulation itself that constantly produces - and produces in a direct ratio of its own energy and extent - a relativity redundant population of laborers, i.e. a population greater than suffices for the average needs of the self-expansion of capital, thus a surplus population ${ }^{3}$.

The noted limits and methodological basis allow us to determine the main trends of changes in the labor market in connection with the digitalization of the economy. Thus, the growth of labor productivity in high-tech digitalized and/or robotized industries is much higher than in industries that are lagging behind in digitalization. The growth in labor productivity is accompanied by a reduction in variable capital due to the release of labor and lower labor costs, alongside the replacement of workplaces with robots. This affects the organic structure of capital, as the organic composition of capital is in a direct ratio constant to variable capital; it can be noted that replacing living labor with capital leads to an increase in organic composition. Technological progress, thus, causes an increase in the labor productivity and the profits of digital platforms and ecosystems for robotized industries, but on the other hand causes an increase in unemployment and a decrease in the rate of profit.

The structure of the economy in the digital age is undergoing even more significant changes than in the era of globalization. Services are becoming the main product of labor, gradually displacing goods. The coronavirus pandemic has further exacerbated this trend; the labor market reacted accordingly. While workplaces in the field of material production were closed, the service sector, on the contrary, required more labor: the delivery of goods, online services from trainers, tutors, consultants, etc. The education and healthcare sectors are actively exploring assorted methods of providing their services online.

The displacements of living labor and the reduction of workplaces have been partially compensated by the creation of new workplaces designed to serve the new needs of capital; thus, new professions related to digital technologies have emerged. However, the problem of retraining those

3 Marx, K. (1995). Capital (Vol. 1). Progress Publisher. 
who have lost their jobs in new competencies, skills, and professions remains a problem. It is unclear who will pay for training; if the state budget pays, it is also unclear from which sources money could be gotten.

In addition, the number of workplaces lost is higher than the number of new workplaces created. With the development of the digital economy, it is possible that these volumes will become equal, and this will be the best development scenario, since an increase in labor productivity will also provide higher incomes through a change in the structure of employment and through reformatting professions in the labor market. However, this positive scenario will be accompanied by a negative one: job cuts and the release of labor force will sharply reduce effective demand, which will remain in part and only for food products in the cheapest price sector. At the same time, the burden of the state budget will increase in order to ensure a neutral social balance and prevent social upheavals.

It is important to note that, in the event of a negative scenario, social upheavals can primarily affect developed countries, since these countries have long observed of a kind of agreement between the state and society about the progressive increase of the level of well-being in exchange for political loyalty. Since roughly the middle of the last century, after the Second World War, measures have been taken in Western countries to ensure that the growth of the population's well-being accompanies citizens throughout their lives; this habit was institutionalized, embedded, and began to be taken for granted as an integral part of the social order. Job cuts and the digitalization of both business and the public sector can change this agreement, even up to its complete cancellation. The perception that a level of well-being is a given is completely different in Eastern and Western countries. Eastern society has not yet gotten used to the growth of prosperity, since each new global economic crisis has led to a reduction in prosperity, followed by growth during boom periods and a new fall during crisis and depressive periods. Western society has experienced crises and depression much less significantly, as their economies recovered faster and remained in a period of prosperity for longer. Today, the social upheavals caused by workplaces cuts and redundancies in the labor force are much more dangerous for developed countries.

This is not to say that Eastern countries will be exempt from workplace cuts, but here citizens are more prepared for difficult times due to their habit of surviving crises in more difficult conditions than their Western comrades. Accordingly, in Eastern countries, the process of replacing material production and consumption with intangible productions and the consumption of specific intellectual-intensive goods and services (based on renewable sources) takes place more slowly. Even now, representatives of Eastern countries are demonstrating creativity, resourcefulness, and a zeal for quality education, while Western societies are rather depressive, since the picture of the world that has formed over 70 years is dramatically changing in a manner for which society was not ready. The trend towards the creation of workplaces has been accompanied by a gradual loss of the value of commodity fetishism founded by Karl Marx. Private property rights cease to play an essential role in the formation and development of industrial relations.

It is important to note that changes in the structure of production and a change in the vector from material production to the production of services creates a unique situation for production, whereby it can develop endlessly with the presence of effective demand; this is because the consumption of services, like their production, is associated with the direct participation of the consumer, and consumer needs are known to be limitless. The limit of possibilities for production has shifted towards the curves of consumer budget constraints. This is where the main problem of the digitalization of the economy manifests itself in full, in the form of workplaces cuts and a decrease in effective 
demand, about which Marx wrote. The budget constraint curve will shift the production opportunity curve back, which will lead to a decrease in the rate of return of entrepreneurs.

Some authors point to possible solutions to the problem of laying off workers and reducing workplace volume by increasing the income of such citizens from other sources. Among these authors, it is particularly worth noting Brynjolfsson and McAfee ${ }^{4}$, Coldwell ${ }^{5}$, Ford ${ }^{6}$, Frey and Osborne ${ }^{7}, 0^{\circ}$ sipov $^{8}$, Srnicek and Williams ${ }^{9}$, Stroiteleva, Kalinicheva, Vukovich, and Osipov ${ }^{10}$, Standing ${ }^{11}$, Van Parijs and Vanderborght ${ }^{12}$, and finally the magnificent work of Pissarides ${ }^{13}$.

Their approaches to solving the problem of ensuring effective demand boil down to the formation of new sources of income from the basic income model, and the reduction of taxes for the population with low incomes, using a novel model of the forced corporatization of robotized industries in favor of redundant workers. Taken together, such models can truly support laid-off workers and provide a sufficient level of income for the population to get used to the "creativization" of workplaces with a subsequent increase in their number.

4 Brynjolfsson, E., \& McAfee, A. (2014). The second machine age: Work, progress, and prosperity in a time of brilliant technologies. Norton \& Company.

5 Coldwell, D. A. L. (2019). Negative influences of the 4th industrial revolution on the workplace: Towards a theoretical model of entropic citizen behavior in toxic organizations. International Journal of Environmental Research and Public Health, 16(15), 26-70. https://doi.org/10.3390/ijerph16152670

6 Ford, M. (2015). Rise of the robots. Technology and the threat of a jobless future. Basic Books.

7 Frey, C. B., \& Osborne, M. A. (2017). The future of employment: How susceptible are jobs to computerization? Technological Forecast and Social Change, 114, 254-280. https://doi.org/101016/j.techfore.2016.08.019

8 Osipov, V. S. (2019). The rise of unemployment in the cyber economy. In V. Filippov, A. Chursin, J. Ragulina \& E. Popkova (Eds.). The cyber economy. Contributions to economics (Vol. 2, pp. 105-116). Springer, Cham. https://doi.org/1011007/978-3030-31566-5_11

9 Srnicek, N., \& Williams, A. (2016). Inventing the future. Postcapitalism and a world without work. Verso Books.

10 Stroiteleva, T. G., Kalinicheva, E. Y., Vukovich, G. G., \& Osipov, V. S. (2019). Peculiarities and problems of formation of industry 4.0 in modern Russia. In E. Popkova, Y. Ragulina \& A. Bogoviz (Eds.). Industry 4.0: Industrial revolution of the 21st century. Studies in systems, decision and control (Vol. 169, pp. 145-153). Springer, Cham. https://doi.org/10.1007/978-3-319-94310-714

1 Standing, G. (2008). How cash transfers promote the case for basic income. Basic Income Studies, 3(1), Article 5. https://doi.org/10.2202/1932-0183.1106

12 Van Parijs, P., \& Vanderborght, Y. (2017). Basic income. A radical proposal for a free society and a sane economy. Harvard University Press. https://doi.org/10.1111/spol.12450

13 Pissarides, C. A. (2013). Unemployment in the Great Recession. Economica, 80, 385-403. https://doi.org/10.1111/ecca.12026 
Digital Law Journal. Vol. 1, No. 3, 2020, p. 14-20

Liu Dun, Geng Yuan, Yuan Lunqu / The Age of Digitalization: Tendencies of the Labor Market

The authors' contribution:

Liu Dun - scientific editing, general formulation of research tasks, creating the new term, determination of the development tendencies of 'workplace' concept.

Geng Yuan - editing, creating the new term, analysis of definition 'creativity'.

Yuan Lunqu - scientific editing, determination of research methodology, analysis of the labor market in connection with the digitalization of the world economy, creating the new term.

\section{Вклад авторов:}

Дунь Л. - научное редактирование, общая постановка исследовательских задач, создание нового термина, определение тенденций развития понятия «рабочее место».

Юань Г. - редактирование, анализ определения «креативность», создание нового термина.

Луньцой Ю. - научное редактирование, определение методологии исследования, анализ рынка труда в связи с цифровизацией мировой экономики, создание нового термина.

\section{Information about the authors:}

Liu Dun - Dr. Sci. in Economics, Labor Economics Department, School of Economics and Management, Beijing Jiaotong University, Beijing, People's Republic of China.

Geng Yuan* - Dr. Sci. in Economics, Labor Economics School, Capital University of Economics and Business, Beijing, People's Republic of China.

gengyuan121@163.com

Yuan Lunqu - Professor, Labor Economics Department, School of Economics and Management, Beijing Jiaotong University, Beijing, People's Republic of China.

\section{Сведения $о б$ авторах:}

Дунь Л. - доктор экономических наук, факультет экономики труда, Школа экономики и менеджмента, Пекинский университет Цзяотун, Пекин, Китайская Народная Республика.

Юань Г. * доктор экономических наук, Школа экономики труда, Столичный университет экономики и бизнеса, Пекин, Китайская Народная Республика.

gengyuan121@163.com

Луньцюй Ю. - профессор, факультет экономики труда, Школа экономики и менеджмента, Пекинский университет Цзяотун, Пекин, Китайская Народная Республика. 